Bangladesh J. Bot. 48(1): 169-175, 2019 (March)

\title{
INDUCED SYNTHESIS OF DEFENSE MOLECULES IN TOMATO (SOLAMUM LYCOPERCICUM L.) AGAINST FUSARIUM WILT THROUGH PLANT EXTRACTS
}

\author{
Samir Kr Biswas*, HG Prakesh, Ram Palat and Javed Bahar \\ Department of Plant Pathology, C.S.A. University of Agriculture \& Technology, \\ Kanpur-208002, India
}

Keywords: Tomato, Induced resistance, Fusarium wilt, Plant extract, Soluble protein, Total phenol, Correlation.

\begin{abstract}
Pre-application of plant extracts as resistance inducers provided protection of tomato plants and reduced wilt incidence from $84.46-8.40 \%$ with the minimum in garlic extract treated seedlings followed by neem and zinger extract representing 10.70 and $11.90 \%$, respectively. Treatment with plant extracts as inducers prior to challenge inoculation sensitized the seedlings to produce increased levels of soluble protein with the maximum in garlic extract treated seedlings representing $29.5,32.40$, and $31.6 \mathrm{mg} / \mathrm{g}$ of fresh leaves of 5, 10 and 15 days of pathogen inoculation whereas, in case of control-1 and control- 2 the values were 21.80, 22.50 and $22.00 \mathrm{mg} / \mathrm{g}$ and $18.98,20.90$ and $19.90 \mathrm{mg} / \mathrm{g}$ of fresh leaves, respectively. A high content of phenol, which is an indicator of first stage of defence mechanism, was also recorded maximum in garlic extract treatment as $2.09,2.26$ and $2.18 \mathrm{mg} / \mathrm{g}$ of fresh leaves against $1.50,1.59$ and $1.58 \mathrm{mg} / \mathrm{g}$ and $1.40,1.50$ and $1.46 \mathrm{mg} / \mathrm{g}$ in case of control-1 and control-2 at 5, 10 and 15 days of pathogen inoculation. Correlation coefficient between disease incidence with soluble protein $(\mathrm{r}=-0.572)$ and total phenol $(\mathrm{r}=-0.533)$ showed a negative correlation with disease incidence.
\end{abstract}

\section{Introduction}

Tomato is one of the most valued vegetable crops of the world owing to its high nutritive value as well as its antioxidant and curative properties. Production of tomato is limited due to various pests and diseases among which Fusarium wilt caused by Fusarium oxysporum f. sp. lycopersici is one of the most important ones. The conventional method of its control is based on direct elimination of the pathogen, but researches are going on in search of non-conventional and eco-friendly management measures which can give well return to growers and reduces the environmental pollution. In this context, induced resistance as a technique of phyto-immunity has received a great attention. Various types of biological agents, virulent or avirulent strains of pathogens, plant extracts, crude extracts and chemicals which are not considered as fungicides are used for induction of resistance in various crops (Cohen 1994, Attitalia et al. 1998, De Cal and Melgarejo 2001, Biswas et al. 2012). The physical and bio-chemical changes associated with induction of resistance are also a common phenomenon reported by several workers (Van Loon 1983, Biswas et al. 2003, Arzoo et al. 2012, Biswas et al. 2012,). Aqueous extracts of barley leaves induced oversized papillae formation in barley which in turn produces resistance against powdery mildew (Yokoyama et al. 1991). Therefore, the present investigation was undertaken to study the effect of plant extracts on induction of resistance against Fusarium wilt in tomato.

\section{Materials and Methods}

The present investigation was undertaken during 2016 - 2017 at Department of Plant Pathology, C.S.A. University of Agriculture and Technology, Kanpur, India. The pathogen, Fusarium oxysporum f. sp. lycopersici was isolated from diseased plants sample and was purified

\footnotetext{
*Author for correspondence: <samirkrbiswas@rediffmail.com>.
} 
by hyphal tip method (Arzoo et al. 2012). The pathogen was identified on the basis of morphological and cultural characteristics as described by Synder and Hansen (Sacc.) (1940). The culture of the pathogen was maintained on PDA at $27 \pm 1^{\circ} \mathrm{C}$ for further investigation.

The bark of eucalyptus, neem leaves, onion bulb, garlic cloves, tubers of motha, ginger rhizome and parthenium leaves were collected around the vicinity area of C.S.A. University of Agriculture and Technology, Kanpur. The extracts of such plant were used as inducers of resistance in tomato against Fusarium wilt. Exactly $5 \mathrm{~g}$ of each plants part were taken and crushed in mortar and pestle along with distilled water in the ratio of $1: 5$. It was later filtered with muslin cloth and pure extracts were collected for further study. At the time of spraying, the extracts were diluted in $225 \mathrm{ml}$ of distilled water to make final solution of $250 \mathrm{ml}$.

In order to ascertain the activities of different plant extracts as inducers, pot experiments were conducted in glass house complex, Department of Plant Pathology, C.S.A.University, Kanpur. About $30 \mathrm{~cm}$ diameter earthen pots were filled with sterilized soil and water was added to bring the soil in a good tilt. Healthy seedlings of tomato variety, Azad T-6 were sown in earthen pots. After one month, plants were sprayed with different plant extract solutions separately. After two days of spraying, all the treated plants except control-1 were inoculated with spore suspension of the pathogen. The concentration of conidia was maintained at $10^{6}$ conidia $/ \mathrm{ml}$. Two controls were kept, in one case, plants were sprayed with distilled water only served as control-1 and in another case, plants were inoculated with conidial suspension of fungus served as control-2. Three replications were kept for each treatment. Then, all the plants were kept on glasshouse bench at 25 $\pm 1^{\circ} \mathrm{C}$.

The measurement of disease incidence was taken after 5, 10 and 15 days of pathogen inoculation. The disease incidence was recorded by using $0-4$ scale where 0 represent as no infection, 1= slight infection, where $25 \%$ leaves become wilted and one or two leaves became yellow, 2 moderate infection, two or three leaves became yellow, $50 \%$ of leaves became wilted, 3 = extensive infection, the all plant leaves became yellow, $75 \%$ of leaves became wilted, and growth is inhibited and $4=$ complete infection, the whole plant leaves became yellow, $100 \%$ of leaves became wilted, and the plants died (Weitang et al. 2004).

The percentage of disease incidence was determined using the formula given by Weitang et al. (2004).

$$
\text { Disease incidence }(\%)=\frac{(\Sigma \text { Scale } \times \text { number of plants infected })}{(\text { Highest scale } \times \text { total number of plants }} \times 100
$$

Tomato leaves were collected from different treatments and the changes in the content of soluble protein and phenol in leaves were estimated at 5,10 and 15 days after inoculation of the pathogen.

Tomato leaves from different treatments were harvested, washed with distilled water and blotter dried before protein extraction. A quantity of $1.0 \mathrm{~g}$ of each sample was cut into small pieces and grinded in pestle and mortar using $1: 5$ (leaves : extraction buffer). The suspension was centrifuged at $10,000 \mathrm{rpm}$ for $30 \mathrm{~min}$ at $4^{\circ} \mathrm{C}$. The supernatant was collected and used for quantification of protein.

The method developed by Lowry et al. (1951) was used with slight modification for quantification of the total soluble protein content. The working standard solution was pipette out as $0.2,0.6$ and $1.0 \mathrm{ml}$ and put into series of test tubes. A quantity of $0.2,0.6$ and $1.0 \mathrm{ml}$ of the sample extract was also pipetted out and kept into other test tubes, separately. Then volumes in all the tubes were made up to $1 \mathrm{ml}$ with distilled water. A tube with $1 \mathrm{ml}$ of distilled water served as a blank. Later on, $5 \mathrm{ml}$ of solution $\mathrm{C}$ was added in each test tube and incubated at room temperature 
for $10 \mathrm{~min}$. Thereafter, $0.5 \mathrm{ml}$ of FCR was mixed well immediately and incubated at room temperature for $30 \mathrm{~min}$ in dark place. The absorbance at $660 \mathrm{~nm}$ against the blank was read and standard graph was drawn to calculate the amount of soluble protein in sample and represented as $\mathrm{mg} / \mathrm{g}$ of fresh leaf sample.

The accumulation of phenols in tomato plants after treatment with different inducers followed by inoculation of pathogen was estimated following procedure developed by Bray and Thorpe (1954) with slight modification. In this method, the total phenol estimation was carried out with Folin-Ciocalteu reagent (FCR), which was measured at $650 \mathrm{~nm}$ wave length calorimetrically.

Exactly, $1.0 \mathrm{~g}$ of leaf sample of tomato was ground in a pestle and mortar in 10 times volume of $80 \%$ ethanol. It was then centrifuged to homogenate the suspension at $10,000 \mathrm{rpm}$ for $30 \mathrm{~min}$ at room temperature. Supernatant was separated and re-extracted for 5 times with required volume of $80 \%$ ethanol, centrifuged and the supernatant were pooled. It was then evaporated near to dryness and residues were dissolved in $5 \mathrm{ml}$ of distilled water. Different aliquots $(0.2,0.6$ and $1.0 \mathrm{ml})$ were pipetted out into test tubes and the volume in each tube was made to $3 \mathrm{ml}$ with distilled water. Subsequently $0.5 \mathrm{ml}$ of FCR was added and after three min, $2 \mathrm{ml}$ of $20 \% \mathrm{Na}_{2} \mathrm{CO}_{3}$ solution in each tube was thoroughly mixed. Then tubes were placed in boiling water for $1 \mathrm{~min}$ and then cooled at room temperature. Then absorbance at $650 \mathrm{~nm}$ against blank was measured using Ultra Violet Visible (UV-VIS) spectrophotometer and the standard curve using different concentrations of phenol was prepared. From the standard curve the concentration of phenols in the test samples was determined and expressed as $\mathrm{mg}$ phenols per $\mathrm{g}$ of sample materials.

Correlation coefficients (r) between soluble protein and disease incidence as well as between total phenol and disease incidence were calculated by standard statistical calculation.

\section{Results and Discussion}

The effect of pre-inoculation spray of plant extracts on tomato plants revealed that there was a decline in wilt incidence in various treatments under glasshouse condition (Table 1). The susceptible variety Azad T-6 of tomato showed 58.45, 65.28 and 84.46 per cent wilt incidence at 5, 10 and 15 days after pathogen inoculation in case of Fusarium oxysporum f. sp. lycopersici treated plants whereas 4.25, 5.65 and 8.40 in case of garlic extract treated plants which were the lowest among the treatments. The neem extract treated plant showed 5.82, 8.00 and 10.70 per cent disease incidence at 5,10 and 15 days after pathogen inoculation indicating second best among the treatment. The decrease in disease incidence might have attributed to the activities of plant extracts which acted as inducers in inducing resistance in plant against Fusarium oxysporum f. sp. lycopersici. The present findings are also supported by several workers who reported that the application of biotic and abiotic inducers have elicited induced resistance in many plants, viz., tomato, potato etc. (Girdhari et al. 2008, Kumar and Biswas 2010, Arzoo et al. 2012, Kumar et al. 2017 and). Rajik et al. (2012) also reported that pre-treatment with biotic inducers provided induced resistance in plant against Fusarium oxysporum f. sp. lycopersici resulting declined disease incidence from $100-7.69$ per cent.

The soluble protein content (Table 2) was found to increase in all treatments but the maximum was noted in garlic extract treated plant representing the value 27.50, 32.40 and 31.60 $\mathrm{mg} / \mathrm{g}$ at 5,10 and 15 days, respectively after inoculation against $21.80,22.50$ and $22.00 \mathrm{mg} / \mathrm{g}$ in case of control-1 and 18.98, 20.90 and $19.90 \mathrm{mg} / \mathrm{g}$ in case of control-2. The plant treated with neem extract as inducer recorded $29.00,31.70$ and $31.10 \mathrm{mg} / \mathrm{g}$ of fresh leaves of soluble protein at 5, 10 and 15 days after pathogen inoculation which is second highest among the treatments. From the table it is also apparent that the soluble protein content increased after 5 to 10 days of pathogen inoculation but it again decreased after 10 - 15 days, indicating that maximum production of 
soluble protein synthesis takes place at 10 days which perhaps provided protection against pathogen infection. The reduced disease incidence indicates that some protein must be associated with induction of resistance against the pathogen. Biswas et al. (2003) also reported that some new proteins were associated with resistance to Bipolaris sorokiniana induced by crude extracts of Chaetomium globosum. The possible role of the new proteins for induction of resistance was speculated. Antoniew et al. (1980) considered that PR-proteins are involved with defense in plants to pathogens. Arzoo et al. (2012) also reported that the maximum increase in protein content was in garlic extract treated seedlings after 15 days of pathogen inoculation.

Table 1. Effect of plant extracts as resistance inducers on disease incidence of Fusarium wilt of tomato.

\begin{tabular}{|c|c|c|c|c|}
\hline \multirow{2}{*}{$\begin{array}{l}\text { Sl. } \\
\text { No. }\end{array}$} & \multirow[t]{2}{*}{ Treatment } & \multicolumn{3}{|c|}{ Disease incidence (\%) } \\
\hline & & 5 days & 10 days & 15 days \\
\hline 1. & Eucalyptus lanceolotus & 12.25 & 17.80 & 20.75 \\
\hline 2. & Azadirachta indica & 5.82 & 8.00 & 10.70 \\
\hline 3. & Allium сера & 8.24 & 11.50 & 14.90 \\
\hline 4. & Allium sativum & 4.25 & 5.65 & 8.40 \\
\hline 5. & Cypus rotundus & 10.34 & 13.84 & 16.86 \\
\hline 6. & Zingiber officinale & 6.02 & 9.90 & 11.90 \\
\hline 7. & Parthenium hysterophorus & 14.24 & 18.85 & 22.00 \\
\hline 8. & Control-1 (Healthy) & 0.00 & 0.00 & 0.00 \\
\hline 9. & Control-2 (Diseased) & 58.45 & 65.28 & 84.46 \\
\hline \multicolumn{2}{|c|}{$\mathrm{SEm} \pm$} & 0.65 & 0.61 & 0.72 \\
\hline \multicolumn{2}{|c|}{ CD at 0.05} & 1.98 & 1.94 & 2.02 \\
\hline \multicolumn{2}{|l|}{$\mathrm{CV}$} & 8.61 & 6.71 & 5.56 \\
\hline
\end{tabular}

Table 2. Effect of foliar spray with plant extract on total soluble protein content of tomato leaves after 5,10 and 15 days of pathogen inoculation.

\begin{tabular}{llccccc}
\hline \multirow{2}{*}{$\begin{array}{l}\text { Sl. } \\
\text { No. }\end{array}$} & Treatment & \multicolumn{3}{c}{$\begin{array}{c}\text { Total soluble protein content } \\
\mathrm{mg} / \mathrm{g} \text { fresh leaves }\end{array}$} & $\begin{array}{c}\text { \% increase at 10 days after } \\
\text { inoculation }\end{array}$ \\
\cline { 3 - 7 } & & 5 days & 10 days & 15 days & Over control-1 & Over control-2 \\
\hline 1 & Eucalyptus lanceolotus & 24.25 & 26.66 & 25.50 & 18.49 & 27.56 \\
2 & Azadirachta indica & 29.00 & 31.70 & 31.10 & 40.89 & 51.67 \\
3 & Allium cepa & 28.27 & 30.56 & 29.68 & 35.82 & 46.22 \\
4 & Allium sativum & 29.50 & 32.40 & 31.60 & 44.00 & 55.02 \\
5 & Cyperus rotundus & 28.40 & 29.75 & 28.25 & 32.22 & 42.34 \\
6 & Zingiber officinale & 30.10 & 31.25 & 30.80 & 38.89 & 49.52 \\
7 & Parthenium hysterophorus & 24.40 & 24.50 & 22.40 & 8.89 & 17.22 \\
8 & Control-1 (Healthy) & 21.80 & 22.50 & 22.00 & - & 7.66 \\
9 & Control-2 (Diseased) & 18.98 & 20.90 & 19.90 & -7.11 & - \\
SEm \pm & 0.89 & 0.85 & 0.92 & & \\
$\mathrm{CD}$ at 0.05 & 2.66 & 2.55 & 2.71 & & \\
$\mathrm{CV}$ & & 5.95 & 5.33 & 5.91 & & \\
\hline
\end{tabular}


Similarly, total phenol content was found to increase in all the plant extract treated plants compared to both the controls. However, the maximum content was found in garlic extract treated plant indicating $2.09,2.26$ and $2.18 \mathrm{mg} / \mathrm{g}$ of fresh leaves at 5,10 and 15 days of pathogen inoculation which were 42.14 and 50.67 per cent increased over control- 1 and control- 2 at 10 days of pathogen inoculation. The healthy plant (control-1) representing as $1.50,1.59$ and $1.58 \mathrm{mg} / \mathrm{g}$ of fresh leaves and disease plant (control-2) as $1.40,1.50$ and $1.46 \mathrm{mg} / \mathrm{g}$ of fresh leaves at 5, 10 and 15 days of pathogen inoculation. Among the treatment, minimum phenol content was found in parthenium treated plant showing $1.54,1.68$ and $1.52 \mathrm{mg} / \mathrm{g}$ of fresh leaves at 5,10 and 15 days of pathogen inoculation. From the Table $\mathbf{3}$ it is also apparent that phenol content was increased from 5 to 10 days and again decreases from 10-15 days of pathogen inoculation. Phenols are involved in disease resistance in many ways like hypersensitive cell death or lignifications of cell walls or increased content of phenol (Nicholson and Hammerschimdt 1992, Kumar 2008, Girdhari et al. 2008, Kumar et al. 2017). Singh et al. (2015) also found that foliar spray with datura extract significantly increased total phenol content at 5,10 and 15th days of pathogen inoculation in tomato against Alternaria solani.

Table 3. Effect of foliar spray with plant extracts on phenol content of tomato leaves after 5, 10 and 15 days of pathogen inoculation.

\begin{tabular}{|c|c|c|c|c|c|c|}
\hline \multirow[t]{2}{*}{$\begin{array}{l}\text { Sl. } \\
\text { No. }\end{array}$} & \multirow[t]{2}{*}{ Treatment } & \multicolumn{3}{|c|}{$\begin{array}{c}\text { Total phenol content } \mathrm{mg} / \mathrm{g} \\
\text { fresh leaves }\end{array}$} & \multicolumn{2}{|c|}{$\begin{array}{c}\% \text { increase at } 10 \text { days } \\
\text { after inoculation }\end{array}$} \\
\hline & & 5 days & 10 days & 15 days & Over control-1 & Over control-2 \\
\hline 1 & Eucalyptus lanceolotus & 1.59 & 1.70 & 1.68 & 6.92 & 13.33 \\
\hline 2 & Azadirachta indica & 2.00 & 2.19 & 2.16 & 37.74 & 46.00 \\
\hline 3 & Allium сера & 1.90 & 2.10 & 2.00 & 32.08 & 40.00 \\
\hline 4 & Allium sativum & 2.09 & 2.26 & 2.18 & 42.14 & 50.67 \\
\hline 5 & Cyperus rotundus & 1.80 & 2.08 & 2.00 & 30.82 & 38.66 \\
\hline 6 & Zingiber officinale & 1.95 & 2.12 & 2.02 & 33.33 & 41.33 \\
\hline 7 & Parthenium hysterophorus & 1.54 & 1.68 & 1.52 & 5.66 & 12.00 \\
\hline 8 & Control-1 (Healthy) & 1.5 & 1.59 & 1.58 & - & 6.00 \\
\hline 9 & Control-2 (Diseased) & 1.40 & 1.50 & 1.46 & -5.66 & \\
\hline \multicolumn{2}{|c|}{ SEm \pm} & 0.15 & 0.13 & 0.11 & & \\
\hline \multicolumn{2}{|c|}{$\mathrm{CD}$ at 0.05} & & 0.41 & 0.37 & & \\
\hline \multicolumn{2}{|c|}{$\mathrm{CV}$} & & 13.94 & 11.41 & & \\
\hline
\end{tabular}

Table 4. Correlation coefficient between disease incidence with soluble protein and total phenol content.

\begin{tabular}{lcc}
\hline Variable & Days & Correlation coefficient \\
\hline Soluble protein & 5 & $\mathrm{r}=-0.664$ \\
& 10 & $\mathrm{r}=-0.572$ \\
Phenol content & 15 & $\mathrm{r}=-0.564$ \\
& 5 & $\mathrm{r}=-0.539$ \\
& 10 & $\mathrm{r}=-0.532$ \\
& 15 & $\mathrm{r}=-0.539$ \\
\hline
\end{tabular}


The leaves treated with plant extracts as inducers provided defense response in plant showed decreased disease incidence with increased level of soluble protein and phenol contents. The correlation coefficient between disease incidence with soluble protein content showed that there is a negative correlation as $-0.664,-0.572$ and -0.564 at 5,10 and 15 days of pathogen inoculation (Table 4). Similarly, negative correlation as $-0.539,-0.532$ and -0.539 has also been found between total phenol and disease incidence at 5,10 and 15 days of pathogen inoculation. Thus, the present finding indicating that the involvement of increase soluble protein and total phenol content in defense response in plant. Similar observations were also found against Fusarium wilt in tomato (Kumar and Biswas 2010, Arzoo et al. 2012).

Pre-inoculation application with plant extracts as inducers provided induced resistance in plants against Fusarium oxysporum f. sp. lycopersici resulting in reduced disease incidence. Prior application of inducers to challenge inoculation sensitized the seedlings to produce increase level of soluble proteins and total phenol content. Both the factors (phenol and protein) have shown negative co-relation with disease severity. Thus, the plant extracts can be used for plant disease management in near future.

\section{References}

Antoniew JF, Ritter CF, Pierpoint WS and Van Loon LC 1980. Comparison of three pathogenesis related proteins from plants of two cultivars of tobacco infected with TMV. J. Gen. Virol. 47: 79-87.

Arzoo K, Biswas SK and Rajik M 2012. Biochemicl evidences of defense responce in tomato against Furarium wilt induced by plant extracts, Plant Pathol. J. 11(2): 42-50.

Attitalila IH, Brishammar S and Camyon C 1998. Effect of soil moistre and temperature on incidence of Fusarium wilt of tomato. J. Mycol. Pl. Pathol. 28: 308.

Biswas SK, Pandey NK and Rajik M 2012. Inductuions of defense responce in tomato against Fusarium wlit through inorganic chemicals as inducer. J. Plant Pathol. and Microbiol. 3(4): 1-7.

Biswas SK, Srivastava KD, Aggarwal R, Shelly Praveen and Singh DV 2003. Biochemical changes in wheat induced by Chaetomium globosum against spot blotch pathogen. Indian Phytopath. 54(4): 374-379.

Bray HC and Thorpe WV 1954. Analysis of phenolic compound of interest in metabolism. Plant Biochem. 1: $27-52$.

Cohen Y 1994. 3 amino butryic acid induces systemic resistance against Perenospora tabacina. Physiol. Mol. Plant Pathol. 44: 273-288.

De Cal A and Melgarejo P 2001. Reported application of P. oxallicum prolongs biocontrol of tomato wilt. Plant Pathol. 46: 72.

Girdhari Lal Kumawat, SK Biswas and Srivastava SSL 2008. Biochemical evidence of defense response in paddy induced by bio-agents against brown leaf spot pathogen. Indian Phytopath. 61 (2): 197-203.

Kumar A 2008. Induced resistance against Fusarium wilt in tomato with inorganic chemicals. M.Sc. Thesis, C.S.A.U.A. \& T., Kanpur. pp. 90.

Kumar A and Biswas SK 2010. Biochemical evidence of induced resistance in tomato against Fusarium wilt through inorganic chemicals. J. Mycopathol. Res. 48(2): 213-219.

Kumar S, Biswas SK, Kumar V, Kishan Lal, Bansal A and Chowdary VT 2017. Induced resistance in potato against late blight caused by Phytophthora infestans (Mont.) De Bary, through calcium chloride. Int. J. Curr. Microbiol. App. Sci. 6(8): 410-417.

Lowary HO, Rosebrough NJ, Farr AL and Randall RJ 1951. Protein measurements with folin phenol reagent. J. Biol. Chem. 193: 265-275.

Nicholson RL and Hammerschmidt R 1992. Phenolic compound and their role in disease resistance. Ann. Rev. Phytopathol. 30: 369-380.

Rajik M, Biswas SK and Shakti S 2012. Biochemical basis of defense response in plant against Fusarium wilt through bio-agents as an inducer. African J. Agril. Res. 7(43): 5849-5857. 
Singh J, Biswas SK, Nagar D and Singh R 2015. Eco-friendly management strategy of Alternaria blight through plant extracts. J. Mycopathol. Res. 53(2): 205-213.

Synder WC and Hansen HN 1940. The species concept in Fusarium. Amer. J. Bot. 27: 64-67.

Van Loon LC 1983. The induction of pathogen cesselated protection by pathogen and specific chemicals. Neth. J. Plant. Pathol. 85: 265-273.

Weitang Song, Ligang Zhou, Chengzong Yang, Xiaodong Cao, Liqun Zhang and Xili Liu 2004. Tomato Fusarium wilt and its chemical control strategies in a hydroponic system. Crop protection 23(3): 120123.

Yokoyama K, Ais JR and Bayles CJ 1991. A papilla regulating extract that induced resistance to barley powdery mildew. Phyl. and Mol. Pant Pathol. 35: 166-175.

(Manuscript received on 12 July, 2018; revised on 20 September, 2018) 